\title{
Reconstructing communities and individuals after conflict and violence: An avant-garde quest for a forgiveness process that includes koinonia and diakonia
}

Author:
Rudy A. Denton ${ }^{1}$
Affiliation:
${ }^{1}$ Unit for Reformational
Theology and the
Development of the SA
Society, Faculty of Theology,
North-West University,
Potchefstroom, South Africa
Corresponding author:
Rudy Denton,
rudydenton@outlook.com
Dates:
Received: 09 Feb. 2021
Accepted: 27 May 2021
Published: 20 July 2021
code with your
How to cite this article:
Denton, R.A., 2021,
'Reconstructing communities
and individuals after conflict
and violence: An avant-garde
quest for a forgiveness online.
process that includes
koinonia and diakonia', In die
Skriflig 55 (2), a2724.
https://doi.org/10.4102/ids.
v55i2.2724
Copyright:
C 2021. The Authors.
Licensee: AOSIS. This work
is licensed under the
Creative Commons
Attribution License.

Overwhelming feelings of resentment and revenge by individuals in emotionally wounded and traumatised communities inflicted by injustice, violence and oppressive systems, often become a way of life, and people seldom deal with forgiveness in their healing process. Too often, the story of traumatic experiences surfaces as an indication of societies struggling to achieve lasting peace. This article explored a process of spiritual healing and life fulfilment that relates to a forgiveness process which includes koinonia and diakonia as indispensable elements on the road to reconstructing communities and individuals following conflict and violence. The point of departure in this article was taken from scriptural and academic literature to provide a forgiveness process to contain revenge and violence without resorting to it, and to protect individuals, communities and the social order within larger systems in society. The imperative to forgive could raise a persistent attitude and a way of life to encourage communities' and individuals' resilience.

Contribution: The article offers an avant-garde quest for a forgiveness process that includes koinonia and diakonia as indispensable elements on the road to reconstructing communities and individuals following conflict and violence.

Keywords: communities; individuals; conflict; violence; forgiveness; koinonia; diakonia.

\section{Introduction}

The concept and role of forgiveness have been increasingly associated with reconstructing communities and individuals following conflict and violence. The connection between anger, resentment and forgiveness to settle the scores in emotionally wounded and traumatised communities, becomes particularly clear in dealing with conflict and violence to maintain peaceful relations. The impact of trauma can overwhelm people and disrupt communities' and individuals' faith, worldview, belief system and perceptions. Given that overwhelming feelings of resentment and revenge often become a way of life, people, affected by injustice, violence and oppressive systems, seldom deal with forgiveness in their healing process.

Within the trauma-ridden societal context of South Africa. which has been subjected to enduring effects of conflict and violence, it seems that forgiveness that includes koinonia and diakonia are underdeveloped concepts within the current discourse on traumatised communities and individuals. This article will address an avant-garde quest for a forgiveness process that includes koinonia and diakonia as indispensable elements on the road to reconstructing individuals and communities after conflict and violence. A more spiritual healing and life fulfilment interpretation of forgiveness (Bash 2011: loc.1302; Webb, Toussaint \& Conway-Williams 2012:66) will depict forgiveness as a means of hope to rebuild communities and individuals' relationships to prevent resentment, revenge and disorder. While it is too premature to judge, this could be a challenge to communities 'to face social changes and individuals' or groups' understanding and conceptualisation of forgiveness' (Denton 2020:212).

The article reflects the contribution of Gert Breed's research on koinonia and diakonia in the wellbeing of individuals and faith communities. A forgiveness process that includes koinonia and diakonia could be indispensable for an avant-garde quest for restorative justice. Initiating a forgiveness process, which includes koinonia and diakonia, has its place in communities tormented by conflict and violence as an attempt to put an end to the transfer of resentment and revenge 
from the present generation to future generations. This perspective should provide an interpretive guide to determine particular strategies and actions or practices of bringing about change (cf. Osmer 2008:176). The imperative to forgive could give rise to an attitude and a way of life which continue to foster the resilience of communities and individuals to manage overwhelming feelings of resentment and revenge, and restore the social order and healing within larger social systems (cf. Denton 2018b).

\section{The impact of conflict and violence on individuals and communities}

Frequent exposure to overwhelming conflict and violence causes psychological and physical harm to victims and generally creates a slow but sure process of physical, emotional and mental exhaustion (Denton 2018b). The experience of trauma affects people's dignity and leave them silenced and wounded with feelings of inferiority, powerlessness, uselessness, ineffectiveness and aimlessness. Gobodo-Madikizela (2002:14) points out that 'inflicted trauma shatters one's sense of self and destroys the sense of continuity between self and others'. The psychological and moral effect of conflict, violence, trauma and suffering can lead to long-term negative effects despite communities' and individuals' defence mechanisms. Breed (2014a:2) emphasises that conflict and violence alienate and frustrate people, and frequently leads to more victimisation and conflict in communities and society. People who suffered the impact of conflict and violence can often succumb to a culture of selfdefence, retaliation and violence due to the post-traumatic effects (cf. Makhulu 2001:377). Gobodo-Madikizela (2020) emphasises that the aftermath of trauma reflects an increasing trend to recognise the enduring effects of conflict and violence in society:

There is also an emerging global perspective and consciousness around identifying the various manifestations of traumatic memory, not only among the generation of survivors who experienced these traumas directly, but also in subsequent generations, among the descendants of survivors. It is now clear that past traumatic experiences are often re-experienced as if the past is happening in the present. (p. 122)

The emotionally draining impact of conflict and violence defines people's experience of human vulnerability and faith. People want to escape suffering, but the reality of life is that pain comes into our lives, as Mildes (2013) points out:

$[W]$ e are left with the psychological, emotional, spiritual, and sometimes physical wounds of our experiences. We gather the broken pieces left and continue to live life with the impact of the emotional stress, yet those experiences carry on within us. (p. 1)

Too often, the story of traumatic experiences surfaces as an indication of societies struggling to achieve lasting peace (cf. Gobodo-Madikizela 2012:260). Wounded and traumatised people think of themselves through a grid of the transgressions and injustices they experienced, as well as the psychological and relational impact of the offences on their being (Denton 2018b; Webb et al. 2012:66). Diane Langberg (2015) gives a good description of what the suffering traumatised people endured:

Trauma means living with the recurrent, tormenting memories of atrocities witnessed or borne. Memories that infect victims' sleep with horrific nightmares destroy their relationships or their capacity to work or study, torment their emotions, shatter their faith, and mutilate hope. Trauma is extraordinary, you see, not because it rarely happens but because it swallows up and destroys normal human ways of living. (pp. 5-6)

Traumatic events are extraordinary and can overwhelm people and disrupt communities' and individuals' faith, worldview, belief system and perceptions. The effects of conflict and violence are most noticeable on those who have social bonds, and it has a way of loosening the bonds that do exist (McAfee 2008:62). Herman (2015) emphasises:

Traumatic events call into question basic human relationships. They breach the attachments of family friendship, love, and community. They shatter the construction of the self that is formed and sustained in relation to others. (p. 51)

Traumatic experiences leave people on their own, abandoned and 'cast out of the human and divine systems of care and protection that sustain life' (Herman 2015:52). It causes overwhelming feelings of resentment and revenge in emotionally wounded individuals and traumatised communities, which often become a way of life, and forgiveness is rarely dealt with in their healing process.

\section{The quest for peaceful living}

The impact of a broken relationship in the past affects interpersonal relationships and the complexity of intergroup social identity in the present and future. The quest for a peaceful living can be the starting point of a process of forgiving the perpetrators that caused the pain and begin anew by creating a clean break with the past - 'to strive to "lift the pain" of the debt through our shared action and belief' (Forster 2018:90). This process can be challenging for both victims and perpetrators within a dedicated construction and reconstruction of their history (cf. Słowikowski 2020:58). Victims and their communities may call for justice against wrongdoing to find their place in a new post-conflict environment. Hartwell (2006:2) emphasises that in the earliest days of a peace process, a cry for justice is the rallying point for traumatised survivors'. In the process of rectification, building and reconstructing a long-term peaceful living social community, the core dynamics of justice and forgiveness are to be found between the tension of justice as restoration and justice-as-punishment. Kiss (2000:79) describes the similarities and differences in restorative and retributive justice in a fashion that highlights essential points for discussion:

Restorative justice includes a threefold commitment (1) to affirm and restore the dignity of those whose human rights have been violated; (2) to hold perpetrators accountable, emphasising the harm that they have done to individual human beings; and (3) to create social conditions in which human rights will be respected. As yet, all of these features are perfectly compatible with retributive justice ... It becomes much sharper when we consider 
a fourth aspect of restorative justice, its commitment to reconciliation. For while retributive justice demands that the guilty be punished, restorative justice, in Tutu's words, 'is concerned not so much with punishment as with correcting imbalances, restoring broken relationships - with healing, harmony and reconciliation'. Thus, a key defining element of restorative justice is its privileging of reconciliation over retribution. (p. 79)

The experience of injustice, which can perpetuate chronic anger, antagonism and the need for retaliation, points to the interdependence of emotion and moral dilemmas. Vorster (2017:381) emphasises that the moral directive for a peaceful resolution to conflicts should be driven by Christian love and compassion. Restorative and retributive justice need to serve the purpose of upholding human rights, restructuring and transforming society and maintaining peace (cf. Vorster 2017:381). The challenge is to connect justice (restorative or retributive) and forgiveness so as to restore the moral order that has been disrupted before healing can occur (Kim 2015:6; Wade, Johnson \& Meyer 2008:97). Kiss (2000:79) identifies the compatibility between restorative and retributive justice, while we can acknowledge that 'they tend to be pursued with different orientations or lived out in different spirits' (Daye 2012:109). Instead of retributive justice embodied in judgement and punishment, restorative justice involves a transformation to steer interpersonal conflict in socially appropriate ways rather than resorting to a pattern of violence and harm. Hartwell (2006:2) emphasises that 'in order to rapidly assess the individuals' and groups' status in an unstable environment ... the ways in which justice is perceived to be fair are extremely important'. According to Tyler (2000):

One clear possible avenue for the peaceful resolution to conflicts is through an understanding of the psychology of social justice. People's views about what is just or fair are a social facilitator through which the interaction among people and groups is enabled. (p. 117)

Social justice is perceived to be fair when remorse, repentance, reparation and forgiveness emerge in a process of reconciliation. Vorster (2007:66) emphasises that 'reconciliation does not replace justice, but is the result of justice'. Restorative justice needs to identify social actions and healing for both victims and perpetrators. That would discontinue the cycle of violence and harm rather than fostering it. Vorster (2017:392) states that the emphasis should be on reparation instead of retaliation.

Thus far, as described in this article, the quest for peaceful living indicates that forgiveness as a process could set the tone for constructive reparation, rehabilitation and reconstruction of disrupted communities and the healing of individuals' overwhelming feelings to minimise and prevent resentment, revenge and disorder. Based on postconflict and the absence of direct and structural violence, social justice (which aims at sustainable peace) should contribute to the continuation of productive interactions among individuals and groups without conflict and societal resentment (Kim 2015:11; Tyler 2000:117). Forgiveness offers a turning point to 'embrace a new way of thinking about one's trauma and about the emotions it evokes' (Gobodo-Madikizela 2002:15). Forgiveness could result in the restoration of communities and reconciliation among individuals and groups. The relational and social process of forgiveness should begin when one perceives oneself as harmed and ends in a challenging psychological reconciliation process with the individual or society responsible for the wounding and injuring.

\section{The process of spiritual healing and life fulfilment}

The process of spiritual healing and life fulfilment relates to forgiveness as a complex and challenging process. It involves spiritual and religious socio-cultural exchanges that should ultimately focus on the revitalisation of interactive, interpersonal relationships and the indispensable mercy, love and forgiveness received from God (Forster 2019:71). Forgiveness involves a way of life and behaviour to maintain peace and a peaceful existence. Jesus Christ came in the world to restore people to the right relationship with one another and with God (Jn 3: 16-17). Migliore (2004:197) emphasises: 'Instead, the deadliness of sin and its cycle of violence are broken once and for all by the costly love and forgiveness of God in Christ.' For that reason, a process of forgiveness leads to a 'horizontal' and 'vertical' dimension (Levinas 2000:20). To restore and recover the dignity of a victim and a perpetrator as a human being with certain unprejudiced principles and values, the sense that people have received forgiveness from God is indispensable in the process of forgiveness. Human dignity and humanity play a decisive and leading role in the act of forgiveness (cf. Grey 2019:52; cf. Słowikowski 2020:72). Gobodo-Madikizela (2003) described the need for forgiveness in the following way:

The victim needs forgiveness as part of the process of becoming rehumanised. The victim needs it in order to complete himself and wrest away from the perpetrator the fiat power to destroy. Far from being an unnerving proposition and a burdensome moral sacrifice, compassion, for many, is deeply therapeutic and restorative. (p. 127)

Baskin and Enright (2004) demarcated forgiveness as:

[T]he will-ful giving up of resentment in the face of another's (or others') considerable injustice and responding with beneficence to the offender even though that offender has no right to the forgiver's moral goodness. (p. 2)

In this context, forgiveness is a gift of grace and reminds wounded people of their own need for divine forgiveness and to live a faithful life in a relationship with God and with one another (cf. Bash 2011: loc.538, 870; Kim 2015:6).

In her classic work, first published in 1958, philosopher and political thinker Hannah Arendt pursued to comprehend how the world could forgive and recover in the aftermath of World War II (Arendt 2018[1958]:240-241, cited by Hartwell 2006:26): 
Forgiveness is the exact opposite of vengeance, which acts in the form of re-acting against an original trespassing, whereby far from putting an end to the consequences of the first misdeed, everybody remains bound to the process, permitting the chain reaction contained in every action to take its unhindered course.

It is forgiveness that releases both victims and perpetrators from the offensive past and offers the prospect of creating a new future (Grey 2019:50). Arendt (2018[1958]:240-241, cited by Hartwell 2006:26; Kim 2015:7) emphasises that:

Without being forgiven, released from the consequences of what we have done, our capacity to act would, as it were, be confined to one single deed from which we could never recover; we would remain the victims of its consequences forever ... Forgiving, in other words, is the only reaction which does not merely react, but acts anew, unexpectedly, unconditioned by the act which provoked it and therefore freeing from its consequences both the one who forgives and the one who is forgiven.

Where resentment and revenge initially appear to be alternatives, forgiveness offers the prospect of creating a new future and a new life of spiritual healing and life fulfilment by abandoning transgression, violence and revenge (cf. Grey 2019:51; cf. Webb et al. 2012:60). Hartwell (1998) points out:

In the end, it may be wise to remember that no matter how much a group promotes or supports a climate for reconciliation and healing, it is the capacity for forgiveness that lies within each individual that arguably influences the long-term success of these efforts. (p. 16)

The ground-breaking engagement of a forgiveness process involves a normative repair that should be sensitive to the offensive past that imposes prejudices in spiritual healing and life fulfilment following conflict and violence. History and memory play a huge part in the perception of persistent offensive injustices and involve more restitution, apology and repentance to resolve, repair or narrow injustices (Bash 2011:1 loc.467). The process of spiritual healing and life fulfilment relates to a forgiveness process that may have a long-term impact on present and upcoming generations to reconstruct communities following conflict and violence, and heal emotionally wounded and traumatised individuals. Forgiveness can play a decisive role to stop the transfer of bitterness and resentment from one generation to the next.

\section{A forgiveness process that includes koinonia and diakonia}

Forgiveness is an act of faith and a response to one person's violation against another. As Christians, individuals and faith communities are responsible for putting forgiveness into practice and expressing compassion in communities wounded by conflict and violence. Individuals in communities, engaged in revenge and self-justification, could find forgiveness, as well as the overcoming of the impact and consequences of conflict and violence, challenging (Denton 2016:6; Macaskill 2005:28). Allers (2010) describes Vladimir Jankélévitch's perspective on the perplexing concept that forgiving the offender also includes forgiving the offence:

Forgiveness aims at the thing that the wicked person did, an act that the evil person committed, a wrong that the evil person bears, or a misdeed for which the evil person made himself responsible. Forgiveness does not only forgive the being, it forgives the doing, or rather the having-done. It forgives the ravages of this being; it forgives the being for these ravages. (p. 21)

Individuals and communities should commit themselves to understand forgiveness, discern when they need to practise it and admit the limitations of their self-effort (Worthington 2009:91). The rational goal of forgiveness, from a Christian viewpoint, should be seen as a process '... to imitate God, to fulfil one's religious duty, to seek God's forgiveness, to follow the path of righteousness, to repair relationships' (Ransley \& Spy 2004:15; cited by Denton 2016:6). Migliore (2004:139) states that 'without God's forgiveness of our sins and our forgiveness of the sins of others against us, no hope of real transformation of life is possible'. In the process of rectification, building and reconstructing a long-term peaceful living community, individuals in communities have the responsibility to embody (personify) resilience and tolerance to put forgiveness into practice.

The process of forgiveness is a multidimensional concept that should reflect cognitive, social, emotional and spiritual dimensions (cf. Webb et al. 2012:66; Ysseldyk \& Matheson 2008:145). People begin the process of forgiveness when they experience themselves as 'wounded by the impact of injustice and ends in giving up negative emotions, thoughts and behaviours towards the offender who was wounding and injuring' (Denton 2016:6). An important step forward in the path of praxis for a post-conflict forgiveness theory is acknowledging that a nuanced conceptualisation of the approach to forgiveness is necessary to address individuals in emotionally wounded and traumatised communities. The process of forgiveness can activate a creative healing process that enables a long-term approach with mutually respectful interchange. The possibility of developing intergroup and interpersonal forgiveness could embrace koinonia and diakonia in the forgiveness process to repair, rehabilitate and reconstruct a post-conflict society.

\section{Koinonia}

The notions of koinonia and diakonia are prominent in unlocking a practical-theological forgiveness process. In the context of koinonia, God requests believers 'to nurture the koinonia that he gave them through the reconciliation work of Jesus Christ and the unity worked by the Holy Spirit' (Breed \& Semenya 2015:6). The New Testament describes koinonia as a theological and ontological unity and not only a sociological unity (Kariatlis 2012:53; Kearsley 2008:18). Through the work of the Holy Spirit, koinonia calls attention to God's gift of grace (1 Cor 12; Ef 2:18-20) to unite believers with God and other believers in the fellowship of the church (the body of Christ) (Davis 2007:53; Oldewage 2014:30-32). Breed and 
Semenya (2015:7) emphasise: 'Whilst Christians should cherish the unique depth of biblical koinonia, they should also seek to live in peace with everyone ( $\mathrm{Rm} \mathrm{12:18)'.}$

The concept of group solidarity offers both sad and joyous moments that are communally shared and celebrated. A valued description of $u b u n t u$ is made by Breed and Semenya (2015:2) that 'a person is a person because of others'. It could be defined as an all-inclusive and other-oriented African worldview grounded on the fundamental principles of humanity and compassion in the quest for peaceful living to ensure a nonviolent community life in the spirit of the family (Denton 2018a:6; cf. Chuwa 2014:13; Gobodo-Madikizela 2020:138-139; Tutu 1999:31). Breed and Semenya (2015) emphasise:

As far as this saying of ubuntu expresses the truth that no one is an island and that people need each other, it corresponds with what koinonia expresses in the New Testament. (p. 7)

The idealisation of communal life and group solidarity, blend in the principle of forgiveness as a process where challenging negative emotions such as bitterness, revenge, resentment, hostility, anger, fear and hatred can be replaced with positive emotions such as empathy, sympathy and love (Kim 2015:159; Webb et al. 2012:66; cf. Worthington, Greer \& Lin 2011:134). It also involves the ethical expectations that require people to decide not to take revenge, but rather to restore the relationship and treat the offender as a valuable person (cf. Worthington et al. 2011:134). Therefore, forgiveness can be described as a restorative practice of healing within the mind and heart of wounded people in the context of interpersonal or intrapersonal relational repair (cf. Denton 2020:225).

As the body of Christ (koinonia), the church should primarily affirm and proclaim a soteriological message. Migliore (2004) emphasise that:

$[W]$ henever forgiveness is offered to others in the name of Christ and received in the power of the Spirit, the deadly circle of violence and counter-violence is broken, and the rule of violence begins to yield to a new world of solidarity, compassion, and peace. (p. 198)

The church's involvement is vital in transforming communities, focusing on developing social, political and economic initiatives, improving peace-building justice, promoting reconciliation and human rights in society, and rebuilding the lives of people who suffer due to unjust systems of conflict and violence. To echo the words of McClure (2012:275-277), the church's communal care or koinonia should guide communities to become 'both the subject and the agent of care' and should empower people 'to respond to God's invitation to love more fully and to participate together in building God's gift of life for all'. When they do:

[T] he imperative to forgive should rise to a permanent attitude and become a way of life that reforms or re-frames people's hearts to grant forgiveness even when oppressive systems justify retaliation and perpetrators deserve revenge. (Denton 2018b:1)

\section{Diakonia}

Where diakonia is understood in the sense of koinonia, it calls for a community of faith where church members (as the body of Christ) form living instruments of mutual care and healing (Ries \& Hendriks 2013:4). Breed and Semenya (2015:7) emphasise that 'koinonia in the congregation should be expressed by the diakonia of every member to the congregation'. The close relationship between koinonia and diakonia represents a mutually respectful relationship and sincere concern for individuals and communities who have been wounded and traumatised due to conflict and violence. When God's kingdom is taken as a starting point in the process of forgiveness to repair, rehabilitate and reconstruct a post-conflict community, it affects how the congregation unite (koinonia) and how it engages in its congregational involvement (diakonia). In their article, 'Ubuntu, koinonia and diakonia, a way to reconciliation in South Africa?', Breed and Semenya (2015:6) describe diakonia 'as service to another person or to the congregation under the command of God and to the honour of God (Mk 10:45)'.

It is clear that there is a close connection between the meaning of being called together as a community of faith (koinonia), and becoming involved in social challenges (diakonia). Diakonia is done without the focus on self-interest, but with the gifts of the Holy Spirit (1 Cor 12:1-5) and the fruit of the Spirit (Gl 5:22) to reach people in need and communities in distress (1 Pt 4:7-11; Mt 25:34-40; cf. Van de Beek 2012:416). Believers are called by Jesus (Mt 25:34-40) to express 'not merely sympathy with one another but active and practical compassion' (Louw 2017:12). This involvement of Jesus in the world is more than an outreach to mere physical distress; he also took people very seriously in terms of their broken spiritual condition and relationships (Ries \& Hendriks 2013:2). Van der Ven (2013) describes that:

$[R]$ eligion's first and foremost role is being present in the midst of the needy, care for them, help them, assist them, shape and create concrete conditions to improve their predicament and throw in one's lot with them. (p. 200)

Christian forgiveness involves the psychosocial and physiological change of people's lives and their ability for social equality in their world to heal the brokenness of relationships (cf. Webb et al. 2012:65). Although people grew up and endured suffering and pain in a society full of tormenting trauma, broken families and violence-ridden communities, core values of community life should be protected and preserved in society. Vorster (2017) argues that:

[T] he core values of community life such as respect for life and property, human dignity, 'ubuntu', sexual morality, family life, the otherness of others, trustworthiness, honesty, diligence and many other values should be strengthened in the society. (p. 396)

With such a holistic understanding, the congregational functions of community (koinonia) and service (diakonia) come to the fore (Ries \& Hendriks 2013:4). In this interaction, Ries and Hendriks (2013:4) emphasise that people are not only 
brought together by a shared unity with God and Christ, but their immediate needs (physical, as well as spiritual) are also addressed. Community (koinonia), as shared unity, should protect and preserve core values of community life with no room for injustice, rejection and condemnation, and be a place where the faith community is rediscovered and people can experience forgiveness, love, caring and support (diakonia).

\section{An avant-garde quest for restorative justice in community building}

It is indispensable to move to a more personalistic approach to include koinonia and diakonia in a forgiveness process to repair, rehabilitate and reconstruct a post-conflict community. In this way, persons in society are approached not only in terms of their individuality, but also in terms of the community and structures they live in (Ries \& Hendriks 2013:4). Christian forgiveness involves the credible restructuring and transformation of social relationships to repair and heal the brokenness and separation of wounded and traumatised individuals in their communities (cf. Yao \& Enright 2018:3). An avant-garde quest for restorative justice is vital in a forgiveness process of community building to prevent resentment, revenge and disorder. The avant-garde quest presented in this article is an innovative intergroup and interpersonal forgiveness process of koinonia and diakonia in community building to repair, rehabilitate and reconstruct a post-conflict community. Consequently, the intergroup and interpersonal forgiveness process of koinonia and diakonia emerge in a personalistic approach as an active process whose functions have definite implications in a broader social framework (community, society and even worldwide).

\section{Jesus' parable on forgiveness (Mt 18:21-35)}

The parable of the unmerciful or unforgiving servant was selected, because it deals with forgiveness as a theological (spiritual) and social concept (Forster 2017:3; Van Eck 2015:3). Firstly, the theological concept deals with 'forgiveness as a process that restores relationship with God'; and secondly, the social concept deals with 'the restoration of relationships within a broken community' (Forster 2017:3). For this article's intended purpose, as a public theological reading of Matthew 18 , it is plausible to identify a valuable depiction of forgiveness to include koinonia and diakonia as part of a forgiveness process in community building. For contemporary Christian readers, this framework including forgiveness, koinonia and diakonia can help structure intergroup engagements.

The text of Matthew 18:15-35 presents an intricate understanding of forgiveness. It reflects a discourse to the church community as the body of Christ (koinonia) and discipleship in the world (diakonia) with an emphasis on power relationships within the Matthean community's ethics and social harmony (cf. Chamburuka \& Van Eck 2019:2; Forster 2017:3-5; Van Eck 2015:1). Van Eck (2015:1) and Forster (2017:3) highlight the community discourse of Matthew's Gospel in Matthew 18 and elaborate on 'forgiveness' and the 'release of debt' in the community. Matthew 18:21-35

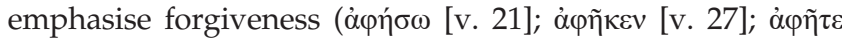
[v. 35]) as a contribution to the well-being of the community by cancelling debt and releasing a person of the debt.

The narrative structure, the genre and content of the text are embedded in a socio-historical system (Forster 2017:4; Nel 2015:2). The 1st-century Mediterranean world was based on domination by the powerful and the value of honour, 'to ensure the preservation of privileged positions and power, and, because it is fundamentally unbalanced, leads to exploitation and debt' (Van Eck 2015:10). The importance of Matthew's ethics was to imitate God's example of unlimited forgiveness through the grace of Jesus to the Matthean community. Firstly, Jesus proclaimed moral and spiritual salvation through Gods' mercy on judgement, instead of Israel's expected political and national liberation (Forster 2017:4; Nel 2015:5-6). Secondly, in addressing the necessity of forgiveness to members' internal conflict within the Matthean community, Matthew 18:15-20 points out 'that each community member has the obligation to seek reconciliation with those who had transgressed against them' (Nel 2015:5).

Since the Matthean community had experienced God's grace, they were 'compelled to extend forgiveness and grace to all - even to their enemies' (Nel 2015:6). Therefore, the parable aimed at general reciprocity, which conflicted with various Mediterranean customs and values based on balanced reciprocity that dominated social relations during the 1st century. Van Eck (2015:10) describes forgiveness or the 'release of debt' based on general reciprocity (Mt 18:33) as follows:

When someone asks for the release of his debt, you show mercy without expecting a socially prescribed response. Honour does not lie in the eye of the beholder, but in the act itself. The release of debt should be given altruistically, that is, not in terms of balanced reciprocity, but in terms of general reciprocity. Where this happens, the basileia of God is visible. (p. 11)

Van Eck (2015:10) points out that 'even though this world is not the basileia, the basileia of God is present in the act itself where debt is released, as the honourable thing to do', in terms of general reciprocity. In the end, Jesus concludes the parable with the rhetorical question (Mt 18:33) to the community (koinonia) that listened to the parable: 'Shouldn't you have had mercy on your fellow servant just as I had on you?'

Regarding the multifaceted complexity of social identity, the community discourse of Matthew's Gospel reveals that victims of injustice have to be treated in ways that justice is perceived to be fair, and perpetrators of conflict and violence have to face restorative justice. The parable (Mt 18:15-35) represents Jesus as a nonviolent man in his mission of compassion to restore people in the right relationship with God and with one another. The discussion, aimed at a forgiveness process, has to transpire in the community with the church's support. The parable addresses the church community as the body of Christ (koinonia) to act in 
forgiveness or 'release of debt', and to be disciples in the world (diakonia), followers of Christ with a focus on rectification, building and reconstructing a peaceful living social community.

\section{The koinonia and diakonia of believers according to 1 Peter}

The first letter from Peter was selected for this article, because it deals with 'God's chosen people' (1 Pt 1:1-2) and Peter's encouragement to the readers in distress to remind them of the Good News about Jesus Christ as their eschatological hope. Within their community of faith, the writer urges them to act as people who belong to Christ. According to 1 Peter $4: 1-5: 10$, they are called to be 'stewards of the rich variety of God's grace' (Breed 2014a:5). As the body of Christ, church members in the community should 'organise their lives according to their identity in Christ' as the 'family of God, stewards of God's grace called to diakonia' (Breed 2014a:9). The church's communal care and responsibility should guide communities to a forgiveness process of koinonia and diakonia. Breed (2014a:3) emphasises that the diakonoi, as the community of faith (koinonia), 'perform their diakonia for the benefit of other people, but the service to other people is primarily a service to God with the purpose of glorifying God'. Breed (2014a) link the diakonoi to Jesus Christ who was sent as the representative of the kingdom of God with a specific commission:

Jesus performed his diakonia as messenger of his Father; therefore, he performed the works of the Father and spoke the words of his Father (Jn 5:36; 14:24). He did nothing out of his own, and the defining motive for his actions was the glorification of the Father. He involved those that followed him in his diakonia so that he could continue his diakonia through them after his ascension. (p. 3)

The role of forgiveness in community building is about communities and individuals' moral formation for the wider society's public prosperity. Breed (2014a) emphasises the instruction of 1 Peter 4: 7-11 to the believers to offer each other a living space through kindness, hospitality, mutual love (which included forgiveness) and willingness to be of service through diakonia:

Their identity as the chosen and pardoned people of God served as motivation to obey the command to serve each other (diakoneo). They were stewards of the rich variety of God's grace. The gifts that God gave them enabled them to manage God's grace in such a manner that the entire congregation would benefit from it. (p. 5)

From a forgiveness point of view, churches should be familiar with the importance of koinonia and diakonia as part of the forgiveness process in community building to prevent resentment, revenge and disorder. However, such a forgiveness process of koinonia and diakonia does not mean that the church or the Christian faith may solve the quest for restorative justice. Instead, it means that the church (as the body of Christ) and the Christian faith community can make a unique contribution to dealing with it. Breed (2014a:5) indicates that 1 Peter 4:7-11 can prepare the community of believers to deal with their alienation in the world (1 Pt 4:1-6, 12-19) by serving each other in such a way that their diakonia (1 Pt 4:11-19) can lead to the reciprocal glorification of God:

The diakonia had to be performed with the strength of God (1 Pt 4:11). The service to each other constituted an important part of the equipment that Peter gave to the believers for their lives as newly born members of the family of God in a hostile world that treated them as aliens. In their poverty which was caused by suffering, they could serve the wealth of God's kingdom to each other. (p. 5)

Breed (2014a:5; 2014b:3; 2016:2; 2019:7) emphasises that 1 Peter 5:1-4 reminds the faith community (koinonia) that they should become the diakonos of each other (as disciples and stewards of God), because 'the Son of Man did not come to be served, but to serve, and to give his life as a ransom for many' (Mk 10:45). This attitude of servanthood should be found 'in people who humbly take care of others and do not seek their own interests' (Breed 2019:7).

\section{The avant-garde quest for a forgiveness process}

An avant-garde quest for a forgiveness process is vital in community building to rectify, rebuild and reconstruct a peaceful living social community. Getting to recognise the overwhelming feelings of resentment and revenge by individuals in emotionally wounded and traumatised communities after conflict and violence is, in fact, the first step on the path to meaningful spiritual healing, life fulfilment, recovery and change. Without negating the lasting impact of conflict and violence on communities and individuals, forgiveness can rejuvenate interpersonal growth and reconstruct new post-conflict communities. A forgiveness process that includes koinonia and diakonia could be an indispensable element of the framework and discourse to address an interpersonal and intergroup social healing process in post-conflict communities. The imperative to forgive should grow into an enduring reaction to survive, as well as a way of life to encourage communities and individuals to deal with tormenting trauma to put forgiveness into practice, even when physical and psychological harm justifies overwhelming feelings of resentment, retaliation revenge and self-justification. An exposition of a forgiveness process, which takes account of koinonia and diakonia, will provide leading change to contain revenge and violence without resorting to it and to protect individuals, communities and the social order within larger systems in society.

From the approach of koinonia and diakonia in this article, it has been argued that an avant-garde quest for restorative justice is vital in a forgiveness process of community building. The Christian faith community (koinonia) can make a distinctive contribution through diakonia to guide communities and individuals to the restructuring and transformation of relationships. The Word of God needs to be lived out in such a way that people with overwhelming feelings of resentment and revenge may receive the guidance of God. They may experience 
him through koinonia and diakonia as the living God of hope and grace actively working in this world and showing mercy to reconstruct individuals and communities after conflict and violence. However, it requires a relationship - an intergroup and interpersonal forgiveness process that takes account of koinonia and diakonia in community building to prevent resentment, revenge and disorder. Breed (2015:7) emphasises that the diakonia of the followers of Jesus entails that they, under the guidance of the Holy Spirit, speak the words and do the deeds of Jesus and the father'. The church's communal care and compassion (koinonia and diakonia) include people who experienced the pain of conflict and violence. Migliore (2004:135) emphasises that it includes those who experience oppression or humiliation to bring them acceptance, dignity, freedom from injustices and hope for restructured and transformed relationships. A forgiveness process that includes koinonia and diakonia is a liberating choice that leads to the restoration of hope for the future, and to refuse to live in bondage to the resentment, revenge and disorder of the past.

\section{Conclusion}

People's deep awareness of their own insecurity currently, makes this a timely article. An avant-garde search for a process of forgiveness intersected meaningfully with a process that includes koinonia and diakonia to restore individuals and reconstruct individuals and communities after conflict and violence. Navigating life's issues and social changes by using forgiveness faithfully, in such a way, will influence the wellbeing of individuals and communities to find hope for a bright and beautiful future. Within a framework and by following a certain trajectory to rejuvenate interpersonal growth and address post-conflict communities, a process of forgiveness engagement that includes koinonia and diakonia could be indispensable elements on the road to restoring individuals and reconstructing communities after conflict and violence. The church (as the body of Christ), communities and individuals are stewards of God's rich grace (koinonia). God sends them to serve people (diakonia); people in need with overwhelming feelings of resentment and revenge in emotionally wounded and traumatised communities.

In conclusion, it is essential that the church equips congregation members in such a way that the search for koinonia between God and his church will inspire them to build a close connection between the meaning of being called together as a community of faith (koinonia), and becoming involved in social challenges (diakonia). When a process of forgiveness focuses on God's kingdom, koinonia is vital for diakonia in community life, and diakonia indispensable for koinonia in community building to repair, rehabilitate and reconstruct communities after conflict and violence. Breed (2015) states that:

God uses the diakonia of his children to draw people to the living King, Jesus Christ, and in doing that, he lets his kingdom come in their hearts and in society and restore order in the chaos. (p. 8)

\section{Acknowledgements Competing interests}

The author have declared that no competing interest exists.

\section{Author's contributions}

R.A.D. declares that he is the sole author of this research article.

\section{Ethical considerations}

This article followed all ethical standards for a research without direct contact with human or animal subjects.

\section{Funding information}

This research received no specific grant from any funding agency in the public, commercial, or not-for-profit sectors.

\section{Data availability}

The authors confirm that the data supporting the findings of this study are available within the article.

\section{Disclaimer}

The views and opinions expressed in this article are those of the author and do not necessarily reflect the official policy or position of any affiliated agency of the author.

\section{References}

Allers, C., 2010, 'Undoing what has been done: Arendt and Levinas on forgiveness', in C.R. Allers \& M. Smit (eds.), Forgiveness in perspective, pp. 19-42, Rodopi, New York, NY.

Arendt, H., 2018[1958], The human condition, University of Chicago Press, Chicago, IL.

Bash, A., 2011, Just forgiveness: Exploring the Bible weighing the issues, SPCK Publishing, London.

Baskin, T.W. \& Enright, R.D., 2004, 'Intervention studies on forgiveness: A metaanalysis', Journal of Counseling \& Development 82(1), 79-90. https://doi. org/10.1002/j.1556-6678.2004.tb00288.x

Breed, G., 2014a, 'The diakonia of practical theology to the alienated in South Africa in the light of 1 Peter', Verbum et Ecclesia 35(1), Art. \#847, 9 pages. https://doi. org/10.4102/ve.v35i1.847

Breed, G., 2014b, 'The meaning of the diakon word group in John 12:26 applied to the ministry in congregations', Verbum et Ecclesia 35(1), Art. \#844,8 pages. https:// doi.org/10.4102/ve.v35i1.844

Breed, G., 2015, 'Finding guidelines on social change in the two-tiered narrative and diakonia in the Gospel of John', HTS Teologiese Studies/Theological Studies 71(2) Art. \#2666, 8 pages. https://doi.org/10.4102/hts.v71i2.2666

Breed, G., 2016, 'The diakonia of the elder according to 1 Peter', In die Skriflig/In Luce Verbi 50(3), a2102. https://doi.org/10.4102/ids.v50i3.2102

Breed, G., 2019, 'The essence and content of the work of the Diakonos according to the New Testament', Scriptura 118(1), 1-11, viewed 12 January 2021, from https://scriptura.journals.ac.za/pub/article/view/1450.

Breed, G. \& Semenya, K., 2015, 'Ubuntu, koinonia and diakonia, a way to reconciliation in South Africa?', HTS Teologiese Studies/Theological Studies 71(2), Art. \#2979, 9 pages. https://doi.org/10.4102/hts.v71i2.2979

Chamburuka, S.W. \& Van Eck, E., 2019, 'Matthean Jesus and forgiveness in light of national healing, peace and reconciliation in Zimbabwe, 2008-2017', HTS Teologiese Studies/Theological Studies 75(3), a5237. https://doi.org/10.4102/hts. v75i3.5237

Chuwa, L.T., 2014, African indigenous ethics in global bioethics: Interpreting Ubuntu, Springer, New York, NY.

Davis, C.M., 2007, 'City lights: Considering the value of an urban-suburban partnership through the lenses of social capital and koinonia', DMin thesis, Palmer Theological Seminary, Wynnewood.

Daye, R., 2012, Political forgiveness: Lessons from South Africa, Wipf \& Stock Publishers, Eugene, OR, viewed 21 December 2020, from https://books.google. co.za/books?id=03t_tgAACAAJ.

Denton, R.A., 2016, 'Die helende krag van regverdige vergifnis, sonder kondonering van onreg', HTS Teologiese Studies/Theological Studies 72(4), a3265. https://doi. org/10.1402/hts.v72i4.3265

Denton, R.A., 2018a, 'Faith and South African realities in practising forgiveness', HTS Teologiese Studies/Theological Studies 74(4), a5176. https://doi.org/10.4102/hts. v74i4.5176 
Denton, R.A., 2018b, 'Forgiveness could shield suffering people in South Africa from overwhelming feelings of withdrawal or impulsive action', paper presented at the 6 th European Conference on Religion, Spirituality and Health, Coventry University, UK, 18 May 2018, viewed 23 October 2020, from https://ecrsh.eu/application/ files/8415/2870/6064/P_11.pdf.

Denton, R.A., 2020, 'Embracing compassion, hospitality, forgiveness and reconciliation The quest for peaceful living in the human displacement crisis', in A.R. Brunsdon The quest for peaceful living in the human displacement crisis', in A.R. Brunsdon
(ed.), The human dilemma of displacement: Towards a practical theology and ecclesiology of home, pp. 207-229, AOSIS, Cape Town.

Forster, D.A., 2017, 'A public theological approach to the (im)possibility of forgiveness in Matthew 18:15-35: Reading the text through the lens of integral theory', In die Skriflig/In Luce Verbi 51(3), a2108. https://doi.org/10.4102/ids.v51i3.2108

Forster, D.A., 2018, 'Translation and a politics of forgiveness in South Africa? What black Christians believe, and white Christians do not seem to understand', STJ/Stellenbosch Theological Journal 4(2), 77-93, viewed 9 January 2021, from https://ojs.reformedjournals.co.za/stj/article/view/1892.

Forster, D., 2019, 'A social imagination of forgiveness', Journal of Empirical Theology 32(1), 70-88, viewed 9 January 2021, from https://brill.com/view/journals/ jet/32/1/article-p70_3.xml.

Gobodo-Madikizela, P., 2002, 'Remorse, forgiveness, and rehumanization: Stories from South Africa', Journal of Humanistic Psychology 42(1), 7-32, viewed 25 May 2021, from http://journals.sagepub.com/doi/10.1177/0022167802421002.

Gobodo-Madikizela, P., 2003, A human being died that night, Houghton Mifflin Boston, MA.

Gobodo-Madikizela, P., 2012, 'Remembering the past: Nostalgia, traumatic memory, and the legacy of apartheid', Peace and Conflict: Journal of Peace Psychology 18(3), 252-267, viewed 25 May 2021, from http://doi.apa.org/getdoi. cfm?doi=10.1037/a0029078.

Gobodo-Madikizela, P., 2020, 'Aesthetics of memory, witness to violence and a call to repair', in K. Wale, P. Gobodo-Madikizela \& J. Prager (eds.), Post-conflict hauntings: Transforming memories of historical trauma, pp. 119-149, Palgrave Studies in Compromise after Conflict, Palgrave Macmillan, Cham, Switzerland. https://doi. org/10.1007/978-3-030-39077-8_6.

Grey, S., 2019, 'Returning to the source', Theoria 66(161), 37-65, viewed 12 December 2020, from http://berghahnjournals.com/view/journals/theoria/66/161/ th6616103.xml.

Hartwell, M.B., 1998, 'The role of forgiveness in reconstructing society after conflict', D.Phil. thesis, Development Studies Queen Elizabeth House Refugee Studies Programme University of Oxford, viewed 30 December 2017, from http://www. jha.ac/articles/a048.htm.

Hartwell, M.B., 2006, 'Perceptions of justice, identity, and political processes of forgiveness and revenge in early post-conflict transitions', The Journal of
Humanitarian Assistance, 1-34, viewed 28 December 2020, from http://sites. Humanitarian Assistance, 1-34, viewed
tufts.edu/jha/files/2011/04/a187.pdf.

Herman, J.L., 2015, Trauma and recovery: The aftermath of violence - from domestic abuse to political terror, Basic Books, New York, N.Y., viewed 28 December 2020, abuse to political terror, Basic Books, New York, N.Y., viewed 28 December 2020,
from https://books.google.co.za/books?id=TVw4DgAQBAJ\&printsec=frontcover from $h$ ttps://books.goog

Kariatlis, P., 2012, 'Affirming koinonia ecclesiology: An orthodox perspective', Phronema 27(1), 51-66, viewed 18 December 2020, from www.sagotc.edu.au/ Phronema 27(1), 51-66, viewed 18 December 2020, from
previous-issues/volume-27-1-2012/abstract-philip-kariatlis/.

Kearsley, R., 2008, Church, community and power, Ashgate Publishing, Surrey.

Kim, J.C., 2015, 'On forgiveness and reconciliation', in Routledge handbook of memory and reconciliation in East Asia, pp. 159-171, Routledge, viewed 18 December 2020, from https://www.taylorfrancis.com/books/9781135009212/ chapters/10.4324/9780203740323-11.

Kiss, E., 2000, 'Moral ambition within and beyond political constraints', in R.I. Rotberg \& D. Thompson (eds.), Truth v. Justice. The morality of truth commissions, pp. 68-98, Princeton University Press, Princeton, NJ.

Langberg, D., 2015, Suffering and the heart of God: How trauma destroys and Chris restores, New Growth Press, Greensboro, NC.

Levinas, E., 2000, Difficult freedom: Essays on Judaism, Athlone Press, Baltimore, MD.

Louw, D.J., 2017, 'Black pain is a white commodity: Moving beyond postcolonial theory in practical theology: \#CaesarMustFall!', HTS Teologiese Studies/ Theological Studies 73(4), a4504. https://doi.org/10.4102/hts.v73i4.4504

Macaskill, A., 2005, 'The treatment of forgiveness in counselling and therapy', Counselling Psychology Review 20(1), 26-32, viewed 26 October 2020, from http://www.bps.org.uk/downloadfile.cfm?file uuid=4326407D-1143-DFD07EE4-8015378EA9A3\&ext=pdf.
Makhulu, W.P.K., 2001, 'Health and wholeness', The Ecumenical Review 53(3), 374-379. https://doi.org/10.1111/j.1758-6623.2001.tb00116.x

McAfee, N., 2008, Democracy and the political unconscious, Columbia University Press, New York, N.Y.

McClure, B., 2012, 'Pastoral care', in B. McClure \& B.J. Miller-McLemore (eds.), The Wiley-Blackwell companion to practical theology, pp. 269-278, Wiley-Blackwell, Oxford.

Migliore, D., 2004, Faith seeing understanding - An introduction to Christian theology, Eerdmans, Grand Rapids, MI.

Mildes, E., 2013, What is trauma and how can Christian counseling help?, viewed 29 December 2020, from https://seattlechristiancounseling.com/articles/what-istrauma-and-how-can-christian-counseling-help-part-1.

Nel, M.J., 2015, 'The motive of forgiveness in the Gospel according to Matthew', In die Skriflig/In Luce Verbi 49(1), Art. \#1917, 9 pages. https://doi.org/10.4102/ids. v49i1.1917

Oldewage, H.E., 2014, 'Fostering koinonia: A critical evaluation of the value of digital social networks in urban congregations', DPhil dissertation, Faculty of Theology, North-West University.

Osmer, R.R., 2008, Practical theology: An introduction, Eerdmans, William B. Publishing Company, Grand Rapids, MI.

Ransley, C. \& Spy, T., 2004, Forgiveness and the healing process: A central therapeutic concern, Brunner-Routledge, Hove, East Sussex, New York, NY.

Ries, J. \& Hendriks, H.J., 2013, 'Koinonia en diakonia as 'n missionale koninkryksdans', HTS Teologiese Studies/Theological Studies 69(2), Art. \#1249, 8 pages. https://doi. org/10.4102/hts.v69i2.1249

Słowikowski, A., 2020, 'Crossroads of forgiveness: A transcendent understanding of forgiveness in Kierkegaard's religious writings and immanent account of forgiveness in contemporary secular and Christian ethics', International Journal for Philosophy of Religion 87(1), 55-80. https://doi.org/10.1007/s11153-019for Philoso

Tutu, D., 1999, No future without forgiveness, Rider, London.

Tyler, T.R., 2000, 'Social justice: Outcome and procedure', International Journal of Psychology 35(2), 117-125. https://doi.org/10.1080/002075900399411

Van de Beek, A., 2012, Lichaam en Geest van Christus: De theologie van de kerk en de Heilige Geest, Uitgeverij Meinema, Zoetermeer.

Van der Ven, J.A., 2013, 'Towards a legitimate role of religion in the domain of socioeconomic rights', in J.A. Van der Ven \& H.-G. Ziebertz (eds.), Human rights and the impact of religion, pp. 167-203, Brill, Leiden.

Van Eck, E., 2015, 'Honour and debt release in the parable of the Unmerciful Servant (Mt 18:23-33): A social-scientific and realistic reading', HTS Teologiese Studies/
Theological Studies 71(1), 71(1), Art. \#2838, 11 pages. https://doi.org/10.4102/ Theological Studie
hts.v71i1.2838

Vorster, J.M., 2017, Ethical perspectives on human rights, Potchefstroom Theological Publications, Potchefstroom.

Vorster, N., 2007, Restoring human dignity in South Africa: Christian anthropology in a new dispensation, Potchefstroom Theological Publications, Potchefstroom.

Wade, N.H., Johnson, C.V. \& Meyer, J.E., 2008, 'Understanding concerns about intervention to promote forgiveness: A review of the literature. Psychotherapy: Theory, research, practice', Training 45, 88-102, viewed 5 December 2020, from http://www.scopus.com/inward/record.url?eid=2-s2.0-84945289801\& partnerID=tZOtx3y1.

Webb, J.R., Toussaint, L. \& Conway-Williams, E., 2012, 'Forgiveness and health Psycho-spiritual integration and the promotion of better healthcare', Journal of Health Care Chaplaincy 18(1-2), 57-73. https://doi.org/10.1080/08854726.2012. 667317

Worthington, E.L., 2009, A just forgiveness: Responsible healing without excusing injustice, InterVarsity Press, Downers Grove, IL.

Worthington, E.L., Greer, C.L. \& Lin, Y., 2011, 'Forgiveness', in T. Clinton \& R. Hawkins (eds.), The popular encyclopedia of Christian counseling: An indispensable tool for helping people with their problems, pp. 134-136, Harvest House Publishing, Eugene, Oregon, $\mathrm{OH}$

Yao, Z. \& Enright, R.D., 2018, 'The link between social interaction with adults and adolescent conflict coping strategy in school context', International Journal of
Educational Psychology 7(1), 1-20, viewed 5 December 2020, from https:// Educational Psychology 7(1), 1-20, viewed 5 Dece
dialnet.unirioja.es/descarga/articulo/6312287.pdf.

Ysseldyk, R. \& Matheson, K., 2008, 'Forgiveness and coping', in W. Malcolm, N. DeCourville \& K. Belicki (eds.), Woman's reflections on the complexities of forgiveness, pp. 143-163, Routledge, New York, NY. 